\title{
Co-occurrent Alterations of Alzheimer's Genes and Prostate Cancer Genes in Prostate Cancer
}

\author{
STEVEN LEHRER ${ }^{1}$ and PETER H. RHEINSTEIN ${ }^{2}$ \\ ${ }^{1}$ Department of Radiation Oncology, Icahn School of Medicine at Mount Sinai, New York, NY, U.S.A.; \\ ${ }^{2}$ Severn Health Solutions, Severna Park, MD, U.S.A.
}

\begin{abstract}
Background: Androgen deprivation therapy (ADT) is extensively employed in treatment of prostate cancer. Some studies have found increased risk of Alzheimer's disease and cognitive impairment in patients treated with ADT. Aim: Since the uncertainty about ADT and dementia might relate to the genetics of prostate cancer and Alzheimer's disease, we used the Cancer Genome Atlas (TCGA) to examine the relationship between genes implicated in Alzheimer's disease and genes implicated in prostate cancer in men with prostate cancer. Materials and Methods: The genomics of 492 prostate cancer cases in the Genomic Data Commons TCGA Prostate Cancer data set were examined. Results: Alterations (mutation, amplification or deletion) in prostate cancer gene speckletype POZ protein (SPOP) significantly co-occurred with alterations in Alzheimer's disease gene bridging integrator-1 (BIN1). Alterations in prostate cancer gene spectrin alpha 1 (SPTA1) significantly co-occurred with alterations in Alzheimer's disease gene CD2-associated protein (CD2AP) $(p<0.001)$. The presence of somatic mutations (deleterious and missense/in frame) in SPOP disturbs BINl gene expression. SPOP and BIN1 RNA expression in 492 prostate cancer specimens was significantly positively correlated $(p<0.001)$. Increased expression of SPOP in 492 cases of prostate cancer was associated with reduced survival $(p=0.00275)$. BIN1 forms part of a network that interacts with the MYC oncogene, which is activated at the earliest phases of prostate cancer and is linked to disease aggressiveness. Men receiving ADT had tumor with a significantly higher Gleason score $(p=0.023)$. Gleason score
\end{abstract}

This article is freely accessible online.

Correspondence to: Dr. Steven Lehrer, Box 1236 Radiation Oncology, Mount Sinai Medical Center, 1 Gustave L. Levy Place, New York 10029, NY, USA. E-mail: steven.lehrer@mssm.edu

Key Words: Genomics, dementia, The Cancer Genome Atlas, prostate, carcinoma. and BIN1 RNA expression in 499 prostate cancer specimens were significantly correlated $(p<0.001)$. Conclusion: The severity of prostate cancer is determined by the genetics of the tumor itself, possibly at least in part by the interactions of SPOP/BIN1, MYC/BIN1 and SPTA1/CD2AP. Oncologists treats higher grade prostate cancer with more $A D T$, which serves as a surrogate marker for disease severity. A weakness of our study is that we did not examine Alzheimer's disease or dementia at all in patients with cancer, only co-occurrence of genetic alterations. Nevertheless, our analysis of TCGA data does not support the idea that ADT causes Alzheimer's disease or dementia.

Androgen deprivation therapy (ADT) is extensively employed in treating prostate cancer. Yet the risk of impaired cognition or Alzheimer's disease in men with prostate cancer receiving ADT is uncertain (1). Some studies of prostate cancer and ADT suggest that risk of Alzheimer's disease is not increased (2-5), although others have found increased risk of Alzheimer's disease and cognitive impairment (6-8).

The uncertainty about ADT and dementia may be related to the genetics of prostate cancer and Alzheimer's disease. In the current analysis, we used the Cancer Genome Atlas (TCGA) to examine the relationship between genes implicated in Alzheimer's disease and genes implicated in prostate cancer in men with prostate cancer.

\section{Materials and Methods}

We examined the genomics of prostate cancer in the Genomic Data Commons (GDC) TCGA Prostate Cancer (PRAD) data set and the MSKCC/DFCI data set (9). The Cancer Genome Atlas (TCGA) contains the analysis of over 11,000 tumors from 33 of the most prevalent forms of cancer (10). To access and analyze the data we used: - UCSC Xena browser, a web-based visual integration and exploration tool for TCGA data, including clinical and phenotypic annotations (11). Gene expression is quantitated as fragments per kilobase of transcript per million mapped reads upper quartile (fpkm-uq), which is an RNA-Seq-based expression normalization method (12). 
Table I. Significantly co-occurring alterations in patients with prostate cancer of speckle-type POZ protein (SPOP), spectrin, alpha 1 (SPTA1), androgen receptor (AR), apolipoprotein E (APOE), bridging integrator-1 (BIN1) and CD2-associated protein (CD2AP). The q-value was derived from the Benjamini Hochberg false-discovery rate correction procedure for multiple comparisons.

\begin{tabular}{|c|c|c|c|c|c|c|c|c|c|}
\hline \multirow{2}{*}{$\begin{array}{l}\text { Gene } \\
\text { A }\end{array}$} & \multirow[b]{2}{*}{$\mathrm{B}$} & \multicolumn{4}{|c|}{ Alteration present, cases } & \multirow[b]{2}{*}{ Odds ratio* } & \multirow[b]{2}{*}{$p$-Value } & \multirow[b]{2}{*}{ q-Value } & \multirow[b]{2}{*}{ Tendency } \\
\hline & & Neither & A Not B & B Not A & Both & & & & \\
\hline SPOP & BIN1 & 425 & 46 & 7 & 11 & $>3$ & $<0.001$ & $<0.001$ & Co-occurrence \\
\hline$A P O E$ & $C D 2 A P$ & 483 & 2 & 1 & 3 & $>3$ & $<0.001$ & $<0.001$ & Co-occurrence \\
\hline SPTAl & $C D 2 A P$ & 459 & 26 & 1 & 3 & $>3$ & $<0.001$ & 0.004 & Co-occurrence \\
\hline SPTA1 & $A P O E$ & 457 & 27 & 3 & 2 & $>3$ & 0.03 & 0.114 & Co-occurrence \\
\hline$C D 2 A P$ & $A R$ & 479 & 3 & 6 & 1 & $>3$ & 0.056 & 0.169 & Co-occurrence \\
\hline$A P O E$ & $A R$ & 478 & 4 & 6 & 1 & $>3$ & 0.07 & 0.175 & Co-occurrence \\
\hline BIN1 & $C D 2 A P$ & 468 & 17 & 3 & 1 & $>3$ & 0.14 & 0.299 & Co-occurrence \\
\hline BIN1 & $A R$ & 465 & 17 & 6 & 1 & 2.189 & 0.232 & 0.435 & Co-occurrence \\
\hline SPOP & SPTAl & 405 & 55 & 27 & 2 & -0.874 & 0.319 & 0.532 & Mutual exclusivity \\
\hline SPOP & $A R$ & 425 & 57 & 7 & 0 & $<-3$ & 0.418 & 0.626 & Mutual exclusivity \\
\hline$S P O P$ & $A P O E$ & 427 & 57 & 5 & 0 & $<-3$ & 0.537 & 0.732 & Mutual exclusivity \\
\hline$S P O P$ & $C D 2 A P$ & 428 & 57 & 4 & 0 & $<-3$ & 0.608 & 0.75 & Mutual exclusivity \\
\hline SPTA1 & $A R$ & 453 & 29 & 7 & 0 & $<-3$ & 0.65 & 0.75 & Mutual exclusivity \\
\hline SPTA1 & BIN1 & 443 & 28 & 17 & 1 & -0.104 & 0.71 & 0.761 & Mutual exclusivity \\
\hline$A P O E$ & BIN1 & 466 & 5 & 18 & 0 & $<-3$ & 0.828 & 0.828 & Mutual exclusivity \\
\hline
\end{tabular}

${ }^{*} \log 2$ value.

- Bioportal, a web-based interface that enables integrative analysis of complex cancer genomics and clinical profiles (13).

- PCViz, an open-source web-based network visualization tool that helps users obtain details about genes and their interactions extracted from multiple pathway data resources.

- Simple statistics were calculated to identify patterns of mutual exclusivity or co-occurrence. For a pair of query genes, an odds ratio (OR) is calculated (Eq. 1) that indicates the likelihood that the events in the two genes are mutually exclusive or co-occurrent across the selected cases

$\mathrm{OR}=(\mathrm{A} \times \mathrm{D}) /(\mathrm{B} \times \mathrm{C})(\mathrm{Eq} .1)$

where A was the number of cases with alteration (i.e. mutated, amplified or deleted) in both genes; B was the number of cases alteration in gene A but not gene B; $\mathrm{C}$ was the number of cases alteration in gene $\mathrm{B}$ but not gene $\mathrm{A}$; and $\mathrm{D}$ was the number of cases without alteration in both genes. Each pair was then assigned to one of three categories indicative of a tendency toward mutual exclusivity, of a tendency toward co-occurrence, or of no association. To determine whether the identified relationship was significant for a gene pair, Fisher's exact test was performed (13). The q-value was derived from the Benjamini Hochberg falsediscovery rate correction procedure for multiple comparisons.

\section{Results}

Five hundred patients with primary prostate cancer, aged $61 \pm 6.8($ mean $\pm \mathrm{SD})$, were included. Overall, $30 \%$ were White, $1.4 \%$ African American, and $0.4 \%$ Asian; of the remainder, race was not recorded. A total of $97 \%$ of cases were prostate adenocarcinoma acinar type. The number of patients with Alzheimer's disease was unknown.
Co-occurrence analysis (Table I) indicated that alterations in the prostate cancer gene speckle-type POZ protein (SPOP) were found to co-occur significantly with alterations in the Alzheimer's disease gene bridging integrator 1 (BIN1) $(p<0.001, \mathrm{q}<0.001)$. Alterations in the prostate cancer gene spectrin alpha, erythrocytic 1 (SPTAl) significantly cooccurred with alterations in the Alzheimer's disease gene CD2-associated protein $(C D 2 A P)(p<0.001, \mathrm{q}=0.004)$. These co-occurring alterations indicate that the genes may work in tandem to drive tumor formation and development.

The presence of somatic mutations (deleterious and missense/in frame) in SPOP deranged BIN1 gene expression. $S P O P$ and BIN1 RNA expression in 492 prostate cancer specimens was found to be significantly positively correlated $(p<0.001$, Figure 1).

Figure 2 shows that BIN1 RNA gene expression $[\log 2$ (fpkm-uq+1)] was significantly negatively correlated with Gleason score in 499 prostate cancer specimens.

Increased expression of SPOP in 492 prostate cancer cases was associated with significantly reduced survival $(p=0.00275)$.

The mean Gleason score of prostate cancer in patients according to receipt of ADT is shown in Figure 3. In those receiving ADT, tumor had a significantly higher Gleason score $(p=0.023)$.

\section{Discussion}

The observed co-existing BIN1/SPOP mutations and expression within prostate cancer tissue might simply reflect 


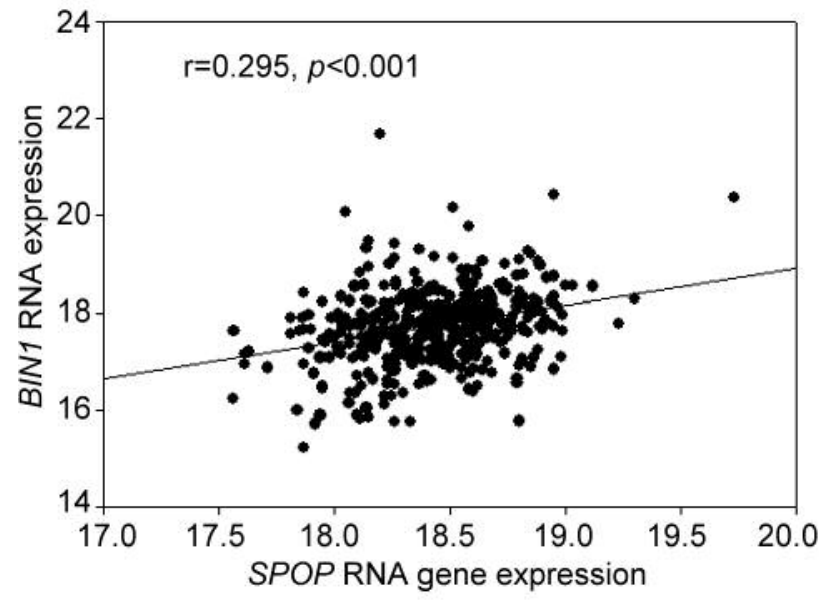

Figure 1. Correlation between speckle-type POZ protein (SPOP) and Alzheimer's disease-associated gene bridging integrator-1 (BIN1) RNA expression [log2 $(f p k m-u q+1)]$ in 492 prostate cancer specimens.

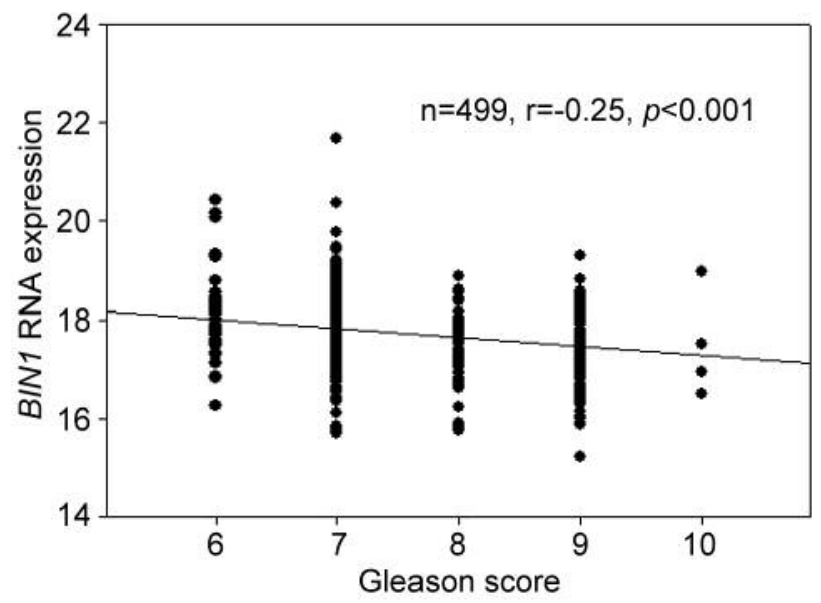

Figure 2. Correlation between Gleason score and Alzheimer's diseaseassociated gene bridging integrator-1 (BIN1) RNA expression [log2 $($ fpkm-uq+1)] in 499 prostate cancer specimens.

tumor-suppressor effects of BIN1 (14). But our finding that $B I N 1$ expression was inversely related to Gleason score might suggest germline BIN1 alterations. Dynamic regulation of the BIN1-Tau interaction is involved in Alzheimer's disease and a high level of BIN1 expression may be protective (15).

BIN1 forms part of a network that interacts with the $M Y C$ oncogene (Figure 4). The MYC family consists of three related human genes; one is c-MYC. The $N$-terminus of the c-MYC oncoprotein interacts with BIN1, which has features of a tumor suppressor (16). MYC is activated at the earliest phases of prostate cancer and in its position on chr8q24 is linked to prostate cancer aggressiveness $(17,18)$.

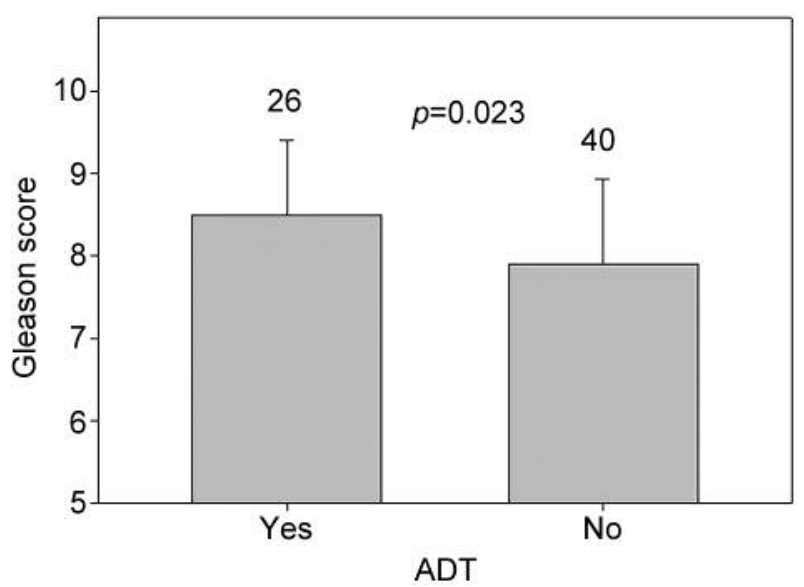

Figure 3. Patients with prostate cancer receiving androgen deprivation therapy (ADT) had a tumor with a significantly higher Gleason score (mean $\pm S D$ ). The number of cases in each group is shown above the corresponding error bar. Data from Genomic Data Commons the Cancer Genome Atlas Prostate Cancer data set.

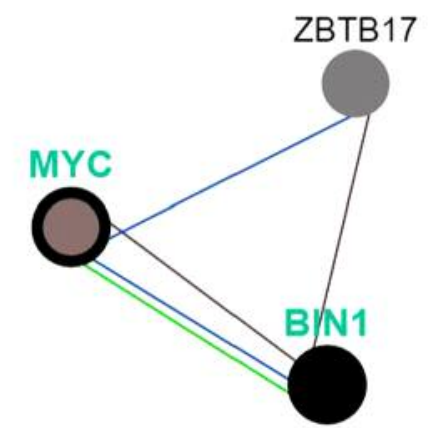

Figure 4. Alzheimer's disease-associated gene bridging integrator-1 (BIN1) forms part of a network that interacts with the MYC oncogene. MYC is altered in $8 \%$ of prostate cancer, and BIN1 in 4\%. Blue line: Controls state of change. Green line: Controls expression. Brown line: Part of a complex. ZBTB17 encodes a zinc finger protein involved in the regulation of c-MYC. (http://www.pathwaycommons.org/pcviz).

CD2AP, a scaffolding molecule regulating signal transduction and cytoskeletal molecules, is implicated in pathogenesis of Alzheimer's disease. Several single nucleotide polymorphisms of $C D 2 A P$ are associated with higher risk for Alzheimer's disease. mRNA levels of CD2AP were found to be reduced in peripheral lymphocytes of patients with sporadic Alzheimer's disease $(18,19)$.

In the largest study of ADT to date, of 154,089 men with prostate cancer, those who underwent ADT had a $14 \%$, and 
$20 \%$ greater chance of developing Alzheimer's disease and of dementia, respectively. Those who received four or fewer doses had a $19 \%$ chance of being diagnosed with either condition, while the five to eight dose group reached $28 \%$ likelihood of Alzheimer's disease and 24\% of dementia; at eight or more doses, the likelihoods were $24 \%$ and $21 \%$, respectively. The study suggests an association between ADT and subsequent dementia but does not investigate possible biological mechanisms of the association. The authors conclude that clinicians need to carefully weigh the longterm risks and benefits of exposure to ADT in patients with a prolonged life expectancy and stratify patients based on dementia risk prior to ADT initiation (8).

Alzheimer's disease symptoms are usually preceded by a preclinical phase that may be 16 years long (20). We propose that ADT dosage reflects the severity of a preclinical phase that has been underway for years. The severity is related to the genetics of the tumor itself, possibly at least in part by the interactions of SPOP/BIN1, MYC/BIN1 and $S P T A 1 / C D 2 A P$. ADT does not appear to cause new cases of Alzheimer's disease, although we have no actual data on Alzheimer's disease for the prostate cancer cohort. Higher grade prostate cancer was associated with more ADT (Figure 3 ), which serves as a surrogate marker for disease severity. In the TCGA data, patients with a higher Gleason score were more likely to receive ADT.

A weakness in our study is that we present somatic mutation data rather than germline data. Co-existing germline mutations would be present in every cell of the body including the brain, where Alzheimer's disease is manifest. A somatic mutation develops in a specific cell and is then propagated to daughter cells. In our study, the cell with the mutation is in the prostate. We are uncertain whether these same mutations co-exist in the brain.

Nevertheless, the idea that ADT causes Alzheimer's disease or dementia in men with prostate cancer is certainly in need of further study.

\section{Conflicts of Interest}

None.

\section{Authors' Contributions}

Each Author contributed to the planning, conduction, and reporting of the work described in the article, and both are responsible for the overall content as guarantors.

\section{References}

1 Zakaib D: Prostate cancer therapy makes dementia more likely. Available at: https: //www.alzforum.org/news/researchnews/prostate-cancer-therapy-makes-dementia-more-likely, 3 July 2019. [Last accessed 20 Nov 2019]
2 Alibhai SM, Timilshina N, Duff-Canning S, Breunis H, Tannock IF, Naglie G, Fleshner NE, Krahn MD, Warde P, Marzouk S and Tomlinson GA: Effects of long-term androgen deprivation therapy on cognitive function over 36 months in men with prostate cancer. Cancer 123(2): 237-244, 2017. DOI: 10.1002/cncr.30320

3 Baik SH, Kury FSP and McDonald CJ: Risk of Alzheimer's disease among senior medicare beneficiaries treated with androgen deprivation therapy for prostate cancer. J Clin Oncol 35(30): 3401-3409, 2017. DOI: 10.1200/JCO.2017.72.6109

4 Lehrer S, Rheinstein PH and Rosenzweig KE: No relationship of anti-androgens to Alzheimer's disease or cognitive disorder in the MedWatch database. J Alzheimers Dis Rep 2(1): 123-127, 2018. PMID: 30480255. DOI: 10.3233/ADR-180052

5 Marzouk S, Naglie G, Tomlinson G, Duff Canning S, Breunis $\mathrm{H}$, Timilshina $\mathrm{N}$ and Alibhai SMH: Impact of androgen deprivation therapy on self-reported cognitive function in men with prostate cancer. J Urol 200(2): 327-334, 2018. PMID: 29477720. DOI: 10.1016/j.juro.2018.02.073

6 Nead KT, Gaskin G, Chester C, Swisher-McClure S, Dudley JT, Leeper NJ and Shah NH: Androgen deprivation therapy and future Alzheimer's disease risk. J Clin Oncol 34(6): 566-571, 2016. DOI: $10.1200 / J C O .2015 .63 .6266$

7 Mohile SG, Lacy M, Rodin M, Bylow K, Dale W, Meager MR and Stadler WM: Cognitive effects of androgen deprivation therapy in an older cohort of men with prostate cancer. Crit Rev Oncol Hematol 75(2): 152-159, 2010. PMID: 20656210. DOI: 10.1016/j.critrevonc.2010.06.009

8 Jayadevappa R, Chhatre S, Malkowicz SB, Parikh RB, Guzzo T and Wein AJ: Association between androgen deprivation therapy use and diagnosis of dementia in men with prostate cancer. JAMA Netw Open 2(7): e196562, 2019. PMID: 31268539. DOI: 10.1001/jamanetworkopen.2019.6562

9 Wedge DC, Gundem G, Mitchell T, Woodcock DJ, Martincorena I, Ghori M, Zamora J, Butler A, Whitaker H, Kote-Jarai Z, Alexandrov LB, Van Loo P, Massie CE, Dentro S, Warren AY, Verrill C, Berney DM, Dennis N, Merson S, Hawkins S, Howat W, Lu YJ, Lambert A, Kay J, Kremeyer B, Karaszi K, Luxton H, Camacho N, Marsden L, Edwards S, Matthews L, Bo V, Leongamornlert D, McLaren S, Ng A, Yu Y, Zhang H, Dadaev T, Thomas S, Easton DF, Ahmed M, Bancroft E, Fisher C, Livni N, Nicol D, Tavare S, Gill P, Greenman C, Khoo V, Van As N, Kumar P, Ogden C, Cahill D, Thompson A, Mayer E, Rowe E, Dudderidge T, Gnanapragasam V, Shah NC, Raine K, Jones D, Menzies A, Stebbings L, Teague J, Hazell S, Corbishley C, Group CS, de Bono J, Attard G, Isaacs W, Visakorpi T, Fraser M, Boutros PC, Bristow RG, Workman P, Sander C, Consortium T, Hamdy FC, Futreal A, McDermott U, Al-Lazikani B, Lynch AG, Bova GS, Foster CS, Brewer DS, Neal DE, Cooper CS and Eeles RA: Sequencing of prostate cancers identifies new cancer genes, routes of progression and drug targets. Nat Genet 50(5): 682-692, 2018. PMID: 29662167. DOI: 10.1038/s41588-0180086-z

10 Hutter C and Zenklusen JC: The Cancer Genome Atlas: Creating lasting value beyond its data. Cell 173(2): 283-285, 2018. PMID: 29625045. DOI: 10.1016/j.cell.2018.03.042

11 Goldman M, Craft B, Swatloski T, Cline M, Morozova O, Diekhans M, Haussler D and Zhu J: The UCSC cancer genomics browser: Update 2015. Nucleic Acids Res 43(Database issue): D812-817, 2015. PMID: 25392408. DOI: 10.1093/nar/gku1073 
12 Shahriyari L: Effect of normalization methods on the performance of supervised learning algorithms applied to htseq-fpkm-uq data sets: 7SK RNA expression as a predictor of survival in patients with colon adenocarcinoma. Brief Bioinform 20(3): 985-994, 2019. PMID: 29112707. DOI: 10.1093/bib/bbx 153

13 Gao J, Aksoy BA, Dogrusoz U, Dresdner G, Gross B, Sumer SO, Sun Y, Jacobsen A, Sinha R, Larsson E, Cerami E, Sander C and Schultz N: Integrative analysis of complex cancer genomics and clinical profiles using the cBIOportal. Sci Signal 6(269): 11, 2013. PMID: 23550210. DOI: 10.1126/scisignal.2004088

14 Ge K, Minhas F, Duhadaway J, Mao NC, Wilson D, Buccafusca R, Sakamuro D, Nelson P, Malkowicz SB, Tomaszewski J and Prendergast GC: Loss of heterozygosity and tumor suppressor activity of BIN1 in prostate carcinoma. Int J Cancer 86(2): 155161, 2000. PMID: 10738240. DOI: 10.1002/(sici)10970215(20000415)86: 2<155: aid-ijc2>3.0.co;2-m

15 Sartori M, Mendes T, Desai S, Lasorsa A, Herledan A, Malmanche N, Makinen P, Marttinen M, Malki I, Chapuis J, Flaig A, Vreulx AC, Ciancia M, Amouyel P, Leroux F, Deprez B, Cantrelle FX, Marechal D, Pradier L, Hiltunen M, Landrieu I, Kilinc D, Herault Y, Laporte J and Lambert JC: BIN1 recovers tauopathy-induced long-term memory deficits in mice and interacts with tau through $\operatorname{Thr}(348)$ phosphorylation. Acta Neuropathol 138(4): 631-652, 2019. PMID: 31065832. DOI: 10.1007/s00401-019-02017-9

16 Pineda-Lucena A, Ho CS, Mao DY, Sheng Y, Laister RC, Muhandiram R, Lu Y, Seet BT, Katz S, Szyperski T, Penn LZ and Arrowsmith $\mathrm{CH}$ : A structure-based model of the cMYC/BIN1 protein interaction shows alternative splicing of BIN1 and c-MYC phosphorylation are key binding determinants. J Mol Biol 351(1): 182-194, 2005. PMID: 15992821. DOI: 10.1016/j.jmb.2005.05.046

17 Koh CM, Bieberich CJ, Dang CV, Nelson WG, Yegnasubramanian S and De Marzo AM: Myc and prostate cancer. Genes Cancer 1(6): 617-628, 2010. PMID: 21779461. DOI: $10.1177 / 1947601910379132$

18 Hollingworth P, Harold D, Sims R, Gerrish A, Lambert JC, Carrasquillo MM, Abraham R, Hamshere ML, Pahwa JS, Moskvina V, Dowzell K, Jones N, Stretton A, Thomas C, Richards A, Ivanov D, Widdowson C, Chapman J, Lovestone S, Powell J, Proitsi P, Lupton MK, Brayne C, Rubinsztein DC, Gill M, Lawlor B, Lynch A, Brown KS, Passmore PA, Craig D, McGuinness B, Todd S, Holmes C, Mann D, Smith AD, Beaumont H, Warden D, Wilcock G, Love S, Kehoe PG, Hooper NM, Vardy ER, Hardy J, Mead S, Fox NC, Rossor M, Collinge J, Maier W, Jessen F, Ruther E, Schurmann B, Heun R, Kolsch H, van den Bussche H, Heuser I, Kornhuber J, Wiltfang J, Dichgans M, Frolich L,
Hampel H, Gallacher J, Hull M, Rujescu D, Giegling I, Goate AM, Kauwe JS, Cruchaga C, Nowotny P, Morris JC, Mayo K, Sleegers K, Bettens K, Engelborghs S, De Deyn PP, Van Broeckhoven C, Livingston G, Bass NJ, Gurling H, McQuillin A, Gwilliam R, Deloukas P, Al-Chalabi A, Shaw CE, Tsolaki M, Singleton AB, Guerreiro R, Muhleisen TW, Nothen MM, Moebus S, Jockel KH, Klopp N, Wichmann HE, Pankratz VS, Sando SB, Aasly JO, Barcikowska M, Wszolek ZK, Dickson DW, GraffRadford NR, Petersen RC, Alzheimer's Disease Neuroimaging I, van Duijn CM, Breteler MM, Ikram MA, DeStefano AL, Fitzpatrick AL, Lopez O, Launer LJ, Seshadri S, consortium C, Berr C, Campion D, Epelbaum J, Dartigues JF, Tzourio C, Alperovitch A, Lathrop M, consortium E, Feulner TM, Friedrich P, Riehle C, Krawczak M, Schreiber S, Mayhaus M, Nicolhaus S, Wagenpfeil S, Steinberg S, Stefansson H, Stefansson K, Snaedal J, Bjornsson S, Jonsson PV, Chouraki V, Genier-Boley B, Hiltunen M, Soininen H, Combarros O, Zelenika D, Delepine M, Bullido MJ, Pasquier F, Mateo I, Frank-Garcia A, Porcellini E, Hanon O, Coto E, Alvarez V, Bosco P, Siciliano G, Mancuso M, Panza F, Solfrizzi V, Nacmias B, Sorbi S, Bossu P, Piccardi P, Arosio B, Annoni G, Seripa D, Pilotto A, Scarpini E, Galimberti D, Brice A, Hannequin D, Licastro F, Jones L, Holmans PA, Jonsson T, Riemenschneider $\mathrm{M}$, Morgan $\mathrm{K}$, Younkin SG, Owen MJ, O'Donovan M, Amouyel $\mathrm{P}$ and Williams J: Common variants at ABCA7, MS4A6A/MS4A4E, EPHA1, CD33 and CD2AP are associated with Alzheimer's disease. Nat Genet 43(5): 429-435, 2011. PMID: 21460840. DOI: $10.1038 / n g .803$

19 Tao QQ, Chen YC and Wu ZY: The role of CD2AP in the pathogenesis of Alzheimer's disease. Aging Dis 10(4): 901-907, 2019. PMID: 31440393. DOI: 10.14336/AD.2018.1025

20 Preische O, Schultz SA, Apel A, Kuhle J, Kaeser SA, Barro C, Graber S, Kuder-Buletta E, LaFougere C, Laske C, Voglein J, Levin J, Masters CL, Martins R, Schofield PR, Rossor MN, Graff-Radford NR, Salloway S, Ghetti B, Ringman JM, Noble JM, Chhatwal J, Goate AM, Benzinger TLS, Morris JC, Bateman RJ, Wang G, Fagan AM, McDade EM, Gordon BA, Jucker $M$ and Dominantly Inherited Alzheimer Network: Serum neurofilament dynamics predicts neurodegeneration and clinical progression in presymptomatic Alzheimer's disease. Nat Med 25(2): 277-283, 2019. PMID: 30664784. DOI: 10.1038/s41591018-0304-3

Received January 27, 2020

Revised March 1, 2020

Accepted March 3, 2020 